\title{
NATIVE YEAST FROM DISTINCT ORGANS OF GRAPEVINES ESTABLISHED IN QUERETARO, MEXICO, AND THEIR POTENTIAL OENOLOGICAL UTILIZATION
}

\section{LEVEDURAS NATIVAS DE DIFERENTES ORGÃOS DE VIDEIRAS INSTALADAS EM QUERETARO, MÉXICO, E A SUA POTENCIAL UTILIZAÇÃO ENOLÓGICA}

\author{
Yamile M. Barragán-Castillo ${ }^{1}$, Dalia E. Miranda-Castilleja ${ }^{1,2}$, Jesús A. Aldrete-Tapia ${ }^{1}$, Sofía M. Arvizu- \\ Medrano $^{1}$, Ramón Á. Martínez-Peniche ${ }^{1^{*}}$
}

\footnotetext{
${ }^{1}$ Cuerpo Académico de Inocuidad Microbiana de los Alimentos, Facultad de Química, Universidad Autónoma de Querétaro. Centro Universitario s/n, Colonia las Campanas. 76010, Querétaro, México.

${ }^{2}$ Universidad Tecnológica de México - UNITEC MÉXICO - Campus Querétaro. Av. 5 de febrero 1412, San Pablo, 76130 Querétaro, México.
}

* Corresponding author: + 4421921200, e-mail: alvar@uaq.mx

(Received 25.10.2019. Accepted 22.06.2020)

\section{SUMMARY}

The aim of this study was to isolate, identify and determine the oenological potential of yeasts present in Vitis vinifera organs of grapevines established in Queretaro State, Mexico. The yeast distribution was influenced by the organ and the sampling season, and the yeast populations ranged from 0.8 and $5.5 \mathrm{Log} \mathrm{CFU} / \mathrm{g}$. A total of 93 yeasts were isolated, identified by RFLP and confirmed by sequencing of the ITS region, prevailing Aureobasidium cf. melanogenum and Basidiomycota yeast. The identified species with previously reported oenological potential were: Pichia cf. kluyveri and Clavispora cf.opuntiae. Remarkably, P. cf. kluyveri 3.1HM showed killer phenotype and was the most tolerant to sulfur dioxide, and survived $72 \mathrm{~h}$ after its inoculation in 'Tempranillo' must. $C$. cf. opuntiae 5.7HM showed $\beta$-glucosidase activity, the highest tolerance to $5 \%$ ethanol and $25{ }^{\circ} \mathrm{Brix}$ (sugar levels). On the contrary, Rhodotorula isolates were not tolerant to stress conditions, and R. mucilaginosa 8HM did not grow under must conditions. Mixed fermentation using H. uvarum NB108/S. cerevisiae N05 resulted in the highest volatile acidity (0.45 $\mathrm{g} / \mathrm{L}$ acetic acid), while no differences for total acidity, alcohol strength, residual sugars and total $\mathrm{SO}_{2}$ were found between the mixed fermentations treatments. This study provides an insight into the yeast diversity present in grapevines established in Queretaro, Mexico, and the oenological potential of. P. cf. kluyveri $3.1 \mathrm{HM}$.

\section{RESUMO}

O objetivo deste trabalho foi isolar, identificar e determinar o potencial enológico de leveduras presentes em órgãos de videiras da espécie Vitis vinifera instaladas no estado de Queretaro, México. A distribuição das leveduras foi influenciada pelo orgão e pela época de amostragem, e as populações de leveduras variaram entre 0,8 e 5,5 Log UFC/g. Nas 93 leveduras isoladas, identificadas por RFLP e confirmadas por sequenciação da região ITS, observou-se uma predominância de Aureobasidium cf. melanogenum e Basidiomycota. As espécies identificadas com potencial enológico previamente relatado foram: Pichia cf. kluyveri e Clavispora cf. opuntiae. Importa salientar que P. cf. kluyveri 3.1HM revelou fenótipo killer e maior tolerância ao dióxido de enxofre, tendo sobrevivido $72 \mathrm{~h}$ após inoculação em mosto de uvas da casta 'Tempranillo'. C. cf. opuntiae $5.7 \mathrm{HM}$ apresentou atividade $\beta$-glucosidase, bem como a maior tolerância a $5 \%$ de etanol e a $25^{\circ}$ Brix (teor de açúcares). Em oposição, os isolados de Rhodotorula não mostraram tolerância às condições de stress, e $R$. mucilaginosa $8 \mathrm{HM}$ não cresceu nas condições do mosto. As fermentações mistas, utilizando $H$. uvarum NB108/S. cerevisiae N05, originaram a acidez volátil mais elevada $(0.45 \mathrm{~g}$ ácido acético/L); não foram detetadas diferenças na acidez total, no título alcoométrico, no teor de açúcares e no teor total de dióxido de enxofre entre as modalidades de fermentação mista. Este estudo permite compreender a diversidade de leveduras presentes em videiras instaladas em Queretaro, México, e o potencial enológico de P. cf. kluyveri 3.1HM.

Key words: Vitis vinifera organs, yeast distribution, non-Saccharomyces, stress conditions, rDNA sequencing. Palavras-chave: Orgãos de Vitis vinifera, distribuição de leveduras, não-Saccharomyces, condições de stress, sequenciação de rDNA. 


\section{INTRODUCTION}

Wine is the beverage resulting from the alcoholic fermentation of grape must and it is carried out by a sequential action of yeasts (OIV, 2019a). During the first steps of fermentation the so-called nonSaccharomyces (n-S) dominate (Jolly et al., 2014). Due to their low tolerance to ethanol, diversity of this group gradually decreases as the fermentation advances and Saccharomyces species become dominant and complete the process (Varela and Borneman, 2017).

During their residency on must fermentation, native yeast especially $\mathrm{n}-\mathrm{S}$, produce certain secondary metabolites, such as glycerol, esters, higher alcohols, medium chain fatty acids, among others, which positively affect the wine quality, conferring higher complexity to wine (Varela, 2016). Moreover, the inoculation of selected native strains to perform must fermentation is blooming, since the strains may be better adapted to the environmental conditions and could also potentiate the tipicity of wines (Callejón et al., 2010; Capozzi et al., 2015; Padilla et al., 2016a; Miranda et al., 2017).

The isolation and selection of oenological yeasts is generally performed from mature grapes and must in fermentation (Belda et al., 2016; Liu et al., 2016; Padilla et al., 2016b). Besides, in vineyards, yeasts could be found on stems, leaves, and on the surface of berries, mainly in stomata, lenticels and sites where microfissures are present (Bernardi, 2013).This yeast diversity was rarely considered to be studied (Garijo et al., 2011), on the belief that strains with oenological potential could be mainly found in wineries.

Yeast genera present in grapevines may be classified into three main groups: a) oxidative yeasts without any oenological interest (Cryptococcus, Sporobolomyces, Aureobasidium); b) mildly fermentative yeasts (Hanseniaspora, Pichia, Metschnikowia); c) fermentative yeasts (Saccharomyces, Torulaspora, Zygosaccharomyces, Lachancea) (Barata et al., 2012).

The recent blooming of the wine industry in Queretaro, Mexico, demands to explore quite new yeast diversity difficult to have in other winemaking areas, where the age of the vineyards and their proximity to wineries has led to a more selected microbiota. Research concerning the selection of native oenological Saccharomyces (MirandaCastilleja et al., 2015) and n-S (Ortiz-Barrera et al., 2015) yeasts has been performed in this region. Nevertheless, there is a lack of information about the diversity and distribution of native yeasts in the vineyard and their possible use in winemaking in Mexico, which could lead to the possibility of finding interesting and original strains with enological benefits. Therefore, the aim of this study was to isolate, identify and determine the oenological potential of yeasts present in different organs of grapevines in the region.

\section{MATERIAL AND METHODS}

\section{Sampling and yeast strains}

Samples were collected from six-year-old grapevines (Vitis vinifera L. cv. 'Tempranillo' grafted on $\mathrm{SO} 4$ rootstock), established in Los Cues, Queretaro, Mexico. The parts of the vines sampled according to their vegetative cycle (Table I) were randomly collected along three lines of the vineyard (triplicate), put into plastic bags $(10 \times 20 \mathrm{~cm})$, transported inside a cooler and immediately processed in the laboratory. The commercial strain S. cerevisiae K1-V1116 (Lalvin, Ontario, Canada) and the native selected strain S. cerevisiae N05 (Miranda-Castilleja et al., 2015) were used. Besides, the sensitive to killer phenotype reference strain AH22 (ATCC38626) as well as two n-S Hanseniaspora uvarum (NB27 and NB108) controls (Ortiz-Barrera et al., 2015) were also used.

Table I

Sampling month and grapevine parts sampled from a 'Tempranillo' vineyard established in Los Cues, Mexico

Mês de amostragem e partes da videira amostradas numa vinha da casta 'Tempranillo' instalada em Los Cues, México

\begin{tabular}{|c|c|c|c|c|c|c|}
\hline \multirow{2}{*}{ Grapevine part } & \multicolumn{6}{|c|}{ Sampling month } \\
\hline & May & June & July & August & September & October \\
\hline Inflorescence & $\mathrm{X}$ & & & & & \\
\hline Fruit set & & $\mathrm{X}$ & & & & \\
\hline Veraison fruit & & & $\mathrm{X}$ & & & \\
\hline Ripe fruit & & & & $\mathrm{X}$ & & \\
\hline Apical leaf & & $\mathrm{X}$ & & & & \\
\hline Medium leaf & & $\mathrm{X}$ & $\mathrm{X}$ & $\mathrm{X}$ & $\mathrm{X}$ & $\mathrm{X}$ \\
\hline Basal leaf & & $\mathrm{X}$ & $\mathrm{X}$ & $\mathrm{X}$ & $\mathrm{X}$ & $\mathrm{X}$ \\
\hline Latent Bud & & & & & & $\mathrm{X}$ \\
\hline
\end{tabular}

\section{Isolation of yeasts}

For each triplicate of sample collected, a total of 50 berries of each physiological state, $3 \mathrm{~g}$ of inflorescences or buds and $5 \mathrm{~g}$ of leaves were placed separately in plastic bags containing $50 \mathrm{~mL}$ of peptone diluent $(0.1 \%$ peptone of casein). Berries 
were carefully and manually homogenized for $3 \mathrm{~min}$. The other samples were homogenized separately in a Stomacher at medium velocity during $1 \mathrm{~min}$. Suspensions were placed in $50 \mathrm{~mL}$ conical tubes and centrifuged at $1790 \mathrm{~g}$ for $10 \mathrm{~min}$ in order to obtain the pellet containing the microorganisms.

Three serial dilutions 1:10 were made and 100 $\mu \mathrm{L}$ were spread plated in nutrient yeast dextrose agar (NYDA, $8 \mathrm{~g} / \mathrm{L}$ nutritive broth, $5 \mathrm{~g} / \mathrm{L}$ yeast extract, 10 $\mathrm{g} / \mathrm{L}$ dextrose and $15 \mathrm{~g} / \mathrm{L}$ agar) supplemented with rose Bengal (100 mg/L) and chloramphenicol (100 mg/L). Plates were incubated at $28{ }^{\circ} \mathrm{C}$ for $48 \mathrm{~h}$, counts were made, and contrasting colony morphologies were isolated in NYDA.

\section{Identification of yeasts species}

For the DNA extraction, a loop of each isolate colony collected from the agar was resuspended in $300 \mu \mathrm{L}$ of TNES (Tris- $\mathrm{HCl} 200 \mathrm{mM} \mathrm{pH} 8.5, \mathrm{NaCl} 250 \mathrm{mM}$, EDTA $25 \mathrm{mM}$, SDS $0.5 \%$ ) and, from this step, the methodology described by Crespo-Sempere et al. (2013) was followed.

For PCR, $2 \mu \mathrm{L}$ of DNA from each isolate were added into $48 \mu \mathrm{L}$ of reaction mix containing: $10 \mu \mathrm{M}$ ITS1 (5' TCCGTAGGTGAACCTGCGG 3'), $10 \mu \mathrm{M}$ ITS4 (5' TCCTCCGCTTATTGATATGC3'), $2 \mathrm{mM}$ of dNTPs, buffer 10X, taq polymerase and PCR-grade water. The PCR reaction was carried out in a Veriti ${ }^{\mathrm{TM}}$ 96-Well Thermal Cycler (Thermo Fisher Scientific, CA, USA) following the next conditions: $95{ }^{\circ} \mathrm{C}$ for 2 min; 35 cycles at $94{ }^{\circ} \mathrm{C}$ for $15 \mathrm{~s}, 55^{\circ} \mathrm{C}$ for $30 \mathrm{~s} ; 72{ }^{\circ} \mathrm{C}$ for $30 \mathrm{~s} ; 72{ }^{\circ} \mathrm{C}$ for $5 \mathrm{~min}$. The PCR products were separated by electrophoresis in $1.3 \%$ agarose gel using $100 \mathrm{~V}$ for $30 \mathrm{~min}$. Then, PCR products were separated in three tubes and restriction enzymes Hha, HaeIII and HinfI were independently added; each reaction was incubated at $37^{\circ} \mathrm{C}$ for $3 \mathrm{~h}$. The obtained fragments after the enzymatic digestion were separated in a $3 \%$ agarose gel. The size of the restriction fragments was determined comparing them with GeneRuler 100 bp DNA ladder (Thermo Scientific, USA) using Gel analyzer plug-in on the Image J software. Then, all the isolates with the same banding pattern were grouped. The distinct banding patterns were compared with the data base from the platform yeast-id.org in order to presumptively identify isolates at species level (Esteve-Zarzoso et al., 1999).

To corroborate the identification by RFLP, representative isolates of each group (one every five with common pattern) were selected or sequencing. Briefly, DNA was extracted and PCR amplicon of ITS region was obtained as previously mentioned, then separated from remaining primers on a $1.5 \%$ agarose gel electrophoresis; the band was excised from the gel and purified using Illustra GFX PCR DNA and Gel Band purification kit (GE Healthcare, Mexico). Purified amplicons on TE buffer were sent to Macrogen Korea (ABI 3730XL 96-capillary DNA analyzer, Applied Biosystems), and then sequence was compared against nucleotide collection of NCBI BLASTN excluding uncultured and model microorganisms sequences, limiting the search on Type material. The sequences were also compared against Mycobank.org databases. In the cases that the RFLP identification of any strain was different from that obtained by sequencing, it was sent for verification by sequencing.

\section{In vitro selection assays}

The isolates previously reported as potentially useful on co-inoculation (Ortiz-Barrera et al., 2015) were selected for the following phenotypic evaluation.

\section{$\beta$-glucosidase activity}

The isolates were streaked by triplicate on esculin glycerol agar plates and incubated at $25{ }^{\circ} \mathrm{C}$ for $72 \mathrm{~h}$. Those with $\beta$-glucosidase activity hydrolyzed the substrate and a dark brown precipitate was observed around the colony (Pérez et al., 2011).

\section{Killer activity}

The killer sensitive strain AH22 (ATCC38626) was pour plated in modified NYDA (methylene blue $0.02 \%, \mathrm{NaCl} 1 \%$ and phosphate-citrate buffer $0.5 \mathrm{M}$, $\mathrm{pH}$ 4.6-4.8) at a final concentration of $5 \mathrm{Log}$ $\mathrm{CFU} / \mathrm{mL}$. A volume of $50 \mu \mathrm{L}$ of overnight culture of isolates to be evaluated were drop inoculated by triplicate and incubated at $25^{\circ} \mathrm{C}$ for $72 \mathrm{~h}$ (Lopes and Sangorrin, 2010). Isolates were considered killer when an inhibition halo around the colony limited by a blue border was observed.

\section{Sugar, sulfur dioxide and ethanol tolerance}

The growth' kinetics of yeasts were measured using a Varioskan (Thermo Fisher Scientific, USA) turbidimetric analyzer. A solution of NYDB (broth with the same composition of NYDA, without agar), at $\mathrm{pH} 3.5$, was prepared and adjusted with: a) sucrose at $25{ }^{\circ}$ Brix, b) $6 \%$ ethanol, or c) $30 \mathrm{mg} / \mathrm{L}$ of sulfur dioxide $\left(\mathrm{SO}_{2}\right)$ using a solution of potassium metabisulfite. A total of $200 \mu \mathrm{L}$ of each medium was added to 96-well plates, and the different yeast isolates were separately inoculated by triplicate at a concentration of $1 \times 10^{5} \mathrm{CFU} / \mathrm{mL}$ and incubated at 25 ${ }^{\circ} \mathrm{C}$. Low agitation was carried out previously to measure the absorbance at $600 \mathrm{~nm}$ every $2 \mathrm{~h}$ and the slope of the exponential phase was estimated (Miranda et al., 2017). 


\section{Winemaking assays}

Crushed grapes cv. 'Tempranillo' were pasteurized at $60{ }^{\circ} \mathrm{C}$ during 20 min (Ribéreau-Gayon et al., 2006) and $700 \mathrm{~mL}$ were distributed in $1 \mathrm{~L}$ flasks. The must presented the following characteristics: $24.2{ }^{\circ} \mathrm{Brix}$, a total titratable acidity of $7.2 \mathrm{~g} / \mathrm{L}$ of tartaric acid, and $\mathrm{pH}$ of 3.82. Musts were first inoculated separately with the $\mathrm{n}-\mathrm{S}$ isolates corresponding to species reported in fermented beverages, or used in mixed fermentations at a concentration of $1 \times 10^{5} \mathrm{CFU} / \mathrm{mL}$ and, after $24 \mathrm{~h}$, with $S$. cerevisiae $\mathrm{N} 05$ at $1 \times 10^{6}$ $\mathrm{CFU} / \mathrm{mL}$. Fermentation was performed at $25^{\circ} \mathrm{C}$, until must density decreased to 1000 . Yeast cell viability was measured every $24 \mathrm{~h}$ during fermentation, for Saccharomyces in NYDA, and for $\mathrm{n}-\mathrm{S}$ in lysine medium (Ortiz-Barrera et al., 2015). At the end of fermentation, $\mathrm{pH}$, alcohol strength, total titritable acidity, volatile acidity, residual sugars and total $\mathrm{SO}_{2}$ (OIV, 2019b) were measured. Three replicates for each treatment were evaluated.

\section{Statistical analysis}

A unifactorial completely randomized design was used for yeast isolates on their tolerance to sugar, ethanol and $\mathrm{SO}_{2}$, as well as for the winemaking assays. In order to establish differences among isolates and evaluate their winemaking performance, ANOVA and Tukey test $(\mathrm{p} \leq 0.05)$ were performed with the obtained data, using the Statistical Program JMP version 11.

\section{RESULTS AND DISCUSSION}

\author{
Quantification of yeast in the different grape \\ organs
}

Quantification of yeast in fruit set were less than 1 $\log \mathrm{CFU} / \mathrm{g}$, while fruits in veraison reached $3 \mathrm{Log}$ CFU/g and ripe fruits $3.7 \mathrm{Log}$ CFU/g averages (Table II). Concerning yeast populations in leaves according to their position along the stem, higher viable concentration on basal leaves with respect to medium and apical leaves were obtained in the distinct sampling dates and an increase of yeasts in the leaves through the time was also observed, reaching values higher than $5 \mathrm{Log} \mathrm{CFU} / \mathrm{g}$ in October.

The values obtained in this study for immature fruits are comparable to those reported by Fleet (2003), ranging from 1 to $3 \mathrm{Log} \mathrm{CFU} / \mathrm{g}$, and for healthy ripe fruits, according to Barata et al. (2012) and Mendes et al. (2017). The differences on yeast viable concentration in the leaves according to their location in the stem could be due to that basal leaves are the oldest, having a longer time of exposure to the vineyard's environment than the others (Pinto et al., 2014). The increase of yeast viable concentration over the time on medium and basal leaves coincides with the use of chemical fungicides in this vineyard, since the application of these products is paused two weeks before ripening, allowing a major accumulation of yeasts. However, many other factors, as topographic and climatic conditions, cultivar and viticultural practices performed in the vineyard affect yeast populations (Cordero-Bueso et al., 2011; Bokulich et al., 2013).

Table II

Yeast viable concentration (Log CFU/g) on grapevines' organs cv. 'Tempranillo' established in Los Cues, Mexico

Concentração de leveduras viáveis ( Log UFC/g) em órgãos de videiras da casta 'Tempranillo' instaladas em Los Cues, México

\begin{tabular}{|c|c|c|c|c|c|c|c|c|}
\hline $\begin{array}{l}\text { Sampling } \\
\text { month }\end{array}$ & Inflorescence & $\begin{array}{l}\text { Fruit } \\
\text { set }\end{array}$ & $\begin{array}{l}\text { Veraison } \\
\text { fruit }\end{array}$ & $\begin{array}{l}\text { Ripe } \\
\text { fruit }\end{array}$ & $\begin{array}{l}\text { Apical } \\
\text { leaf }\end{array}$ & $\begin{array}{l}\text { Medium } \\
\text { leaf }\end{array}$ & $\begin{array}{l}\text { Basal } \\
\text { leaf }\end{array}$ & $\begin{array}{l}\text { Latent } \\
\text { Bud }\end{array}$ \\
\hline May & $2.1 \pm 0.44$ & - & - & - & - & - & - & - \\
\hline June & - & $0.8 \pm 0.54$ & - & - & $2.7 \pm 0.21$ & $2.5 \pm 0.19$ & $3.1 \pm 0.13$ & - \\
\hline July & - & - & $3.5 \pm 0.18$ & - & - & $3.5 \pm 0.27$ & $3.7 \pm 0.16$ & - \\
\hline August & - & - & - & $3.7 \pm 0.11$ & - & $3.0 \pm 0.04$ & $4.0 \pm 0.09$ & - \\
\hline September & - & - & - & - & - & $3.8 \pm 0.19$ & $3.8 \pm 0.10$ & - \\
\hline October & - & - & - & - & - & $5.3 \pm 0.13$ & $5.5 \pm 0.08$ & $5.0 \pm 0.20$ \\
\hline
\end{tabular}

Triplicate data is presented as mean \pm standard deviation. 


\section{Identification of yeast species}

From 93 isolates obtained and their grouping according to their restriction similarity, 14 different banding patterns were found, which corresponded to 10 species identified by PCR-RFLP, while four banding patterns did not match those on the yeastid.org database (Table III).

\section{Table III}

Banding patterns and identification of yeast by PCR-RFLP

Padrões de bandas e identificação de leveduras por PCR-RFLP

\begin{tabular}{|c|c|c|c|c|c|}
\hline $\begin{array}{l}\text { Number } \\
\text { of isolates }\end{array}$ & PCR product $(\mathrm{pb})$ & HhaI (pb) & HaeIII $(\mathrm{Pb})$ & $\operatorname{HinfI}(\mathrm{Pb})$ & $\begin{array}{c}\text { Yeast species } \\
\text { Current name } \\
\text { (synonym or former name) }\end{array}$ \\
\hline 33 & 600 & $100+180+200$ & $150+450$ & $120+170+280$ & Aureobasidium pullulans \\
\hline 1 & 410 & $180+220$ & 410 & $190+210$ & Diutina catenulata \\
\hline 15 & 650 & $300+350$ & $60+90+500$ & $130+245+275$ & $\begin{array}{l}\text { Filobasidium magnum } \\
\text { (Cryptococcus magnus) }\end{array}$ \\
\hline 14 & 490 & $230+260$ & 490 & $240+250$ & $\begin{array}{l}\text { Hannaella luteola } \\
\text { (Cryptococcus luteolus) }\end{array}$ \\
\hline 7 & 630 & $300+330$ & $60+70+500$ & $120+160+350$ & $\begin{array}{c}\text { Naganishia albida } \\
\text { (Cryptococcus albidus) }\end{array}$ \\
\hline 2 & 630 & $300+330$ & $60+70+500$ & $280+350$ & Cryptococcus sp \\
\hline 1 & 550 & $260+290$ & $100+375$ & $270+270$ & Papilotrema laurentii \\
\hline 1 & 445 & $70+90+150$ & $80+330$ & $190+250$ & Pichia fermentans \\
\hline 3 & 550 & $100+200+250$ & $50+500$ & $50+250+250$ & Cyberlidnera petersonii \\
\hline 2 & 625 & $90+220+300$ & $215+405$ & $70+215+340$ & Rhodotorula mucilaginosa \\
\hline 10 & 550 & $200+260$ & 550 & $180+300$ & Unidentified \\
\hline 1 & 600 & 600 & $80+520$ & $140+220+290$ & Unidentified \\
\hline 1 & 630 & $300+350$ & 500 & $180+320$ & Unidentified \\
\hline 2 & 600 & $290+320$ & $110+400$ & $60+110+160+280$ & Unidentified \\
\hline
\end{tabular}

The sequencing of a representative isolate of each one of the 14 restriction banding patterns and their comparison with the nucleotide collection of NCBI led to the identification of 11 isolates at species level and three at genus level (Cryptococcus), all coinciding to species previously reported as abundant on grape surfaces (Zanol et al., 2010) - Table IV. From the 10 species identified by PCR-RFLP, seven coincided in the identification by both methods and three resulted on different species (Diutinacatenulata vs. Clavispora cf. opuntiae, Pichia fermentans vs. Pichia cf. kluyveri and Cyberlidnera petersonii vs. Papiliotrema rajasthanensis. The three isolates identified as Cyberlidnera petersonii by PCR-RFLP and later identified as Papiliotrema rajasthanensis by sequencing of one isolate, were confirmed by sequencing the other two isolates, all resulting in the same species. In the case of the other two different identifications, PCR-RFLP group was constituted by only one isolated each (Table III).

Then there was a subtle discrepancy between the two methods used, which is ascribed to the fact that RFLP is a more general methodology (polymorphism patterns) identifying the yeasts only presumptively. Nucleotide sequencing should be considered as a 
more reliable methodology, since it is more precise at the moment of searching the homology of the sequence in the databases ( $\mathrm{Li}$ et al., 2010).

\section{Table IV}

Comparison of the identity of isolates with different restriction banding patterns obtained by PCR-RFLP and sequencing

Comparação da identidade dos isolados com diferentes padrões de bandas de restrição obtidos por PCR-RFLP e sequenciação

\begin{tabular}{|c|c|c|c|c|}
\hline $\begin{array}{l}\text { Identification of isolate by } \\
\text { PCR-RFLP } \\
\text { Current name } \\
\text { (Synonym or former name) }\end{array}$ & $\begin{array}{l}\text { Identification of the isolate by } \\
\text { sequencing } \\
\text { Current name } \\
\text { (Synonym or former name) }\end{array}$ & Query coverage & e-value & Identity \\
\hline Aureobasidium pullulans & $\begin{array}{l}\text { Aureobasidium cf. melanogenum } \\
\text { (A. pullulans var. melanogenum) }\end{array}$ & $98 \%$ & 0 & $97 \%$ \\
\hline Diutina catenulata & Clavispora cf. opuntiae & $91 \%$ & $2 \times 10^{-148}$ & $96 \%$ \\
\hline $\begin{array}{l}\text { Filobasidium magnum } \\
\text { (Cryptococcus magnus) }\end{array}$ & $\begin{array}{l}\text { Filobasidium magnum } \\
\text { (Cryptococcus magnus) }\end{array}$ & $98 \%$ & 0 & $100 \%$ \\
\hline $\begin{array}{l}\text { Hannaella luteola } \\
\text { (Cryptococcus luteolus) }\end{array}$ & $\begin{array}{l}\text { Hannaellaluteola } \\
\text { (Cryptococcusluteolus) }\end{array}$ & $99 \%$ & 0 & $100 \%$ \\
\hline $\begin{array}{l}\text { Naganishia albida } \\
\text { (Cryptococcus albidus) }\end{array}$ & $\begin{array}{l}\text { Naganishia albida } \\
\text { (Cryptococcus albidus) }\end{array}$ & $100 \%$ & 0 & $100 \%$ \\
\hline Cryptococcus sp & Cryptococcus sp & $100 \%$ & 0 & $99 \%$ \\
\hline Papiliotrema laurentii & $\begin{array}{l}\text { Vishniacozyma carnescens } \\
\text { (Cryptococcus carnescens) }\end{array}$ & $100 \%$ & 0 & $100 \%$ \\
\hline Pichia fermentans & Pichia cf. kluyveri & $99 \%$ & $3 \times 10^{-179}$ & $97 \%$ \\
\hline Cyberlindnera petersonii & $\begin{array}{l}\text { Papiliotrema rajasthanensis } \\
\text { Cryptococcus rajasthanensis) }\end{array}$ & $100 \%$ & 0 & $100 \%$ \\
\hline Rhodotorula mucilaginosa & Rhodotorula mucilaginosa & $99 \%$ & 0 & $100 \%$ \\
\hline Not identified & $\begin{array}{l}\text { Papiliotrema flavescens } \\
\text { (Cryptococcus flavescens) }\end{array}$ & $99 \%$ & 0 & $99 \%$ \\
\hline Not identified & Cryptococcus sp & $99 \%$ & 0 & $99 \%$ \\
\hline Not identified & Cryptococcus sp & $100 \%$ & 0 & $100 \%$ \\
\hline Not identified & Rhodotorula nothofagi & $100 \%$ & 0 & $100 \%$ \\
\hline
\end{tabular}

e-value: Number of expected hits that could be found just by chance on a particular size database.

On the other hand, the absence of the Saccharomyces genus can be attributed to the sampling carried out in a young vineyard, located far from other vines and in absence of a winery, where $S$. cerevisiae prevails (Pérez-Martín et al., 2014; Mendes et al., 2017). Another reason that may explain why no Saccharomyces isolates were detected is that only healthy grapes were sampled. Barata et al. (2012) recovered S. cerevisiae yeasts in post-mature decayed or damaged grapes.

The percentages of relative abundance of the different yeast species found in each organ are shown in Figure 1. Aureobasidium cf. melanogenum predominated throughout the sampling, especially in inflorescences and in the different stages of fruit development. Pichia cf. kluyveri was found in basal leaves and Clavispora cf. opuntiae in medium leaves. Finally, Rhodotorula mucilaginosa and $R$. nothofagi were only found in leaves.

These results coincide with those of Grube et al. (2011) who isolated Aureobasidium pullulans from stems, leaves and grape berries in $26 \%, 41 \%$ and 18 $\%$ respectively, while Garijo et al. (2011) found it predominately in the air of the vineyard during two consecutive years. In this study, Naganishia albida and Papiliotrema flavescens, former Cryptococcus albidus and C. flavescens, respectively, were located in berries, coinciding with $\mathrm{Li}$ et al. (2010) who 
detected the last one in the same organ. The species prevalent in the vineyard are highly oxidative yeasts which do not survive in the anaerobic conditions of must (Varela and Borneman, 2016), however they have been reported as biocontrol agents against diverse fungal diseases (Varela and Borneman, 2016; Wang et al., 2018a).

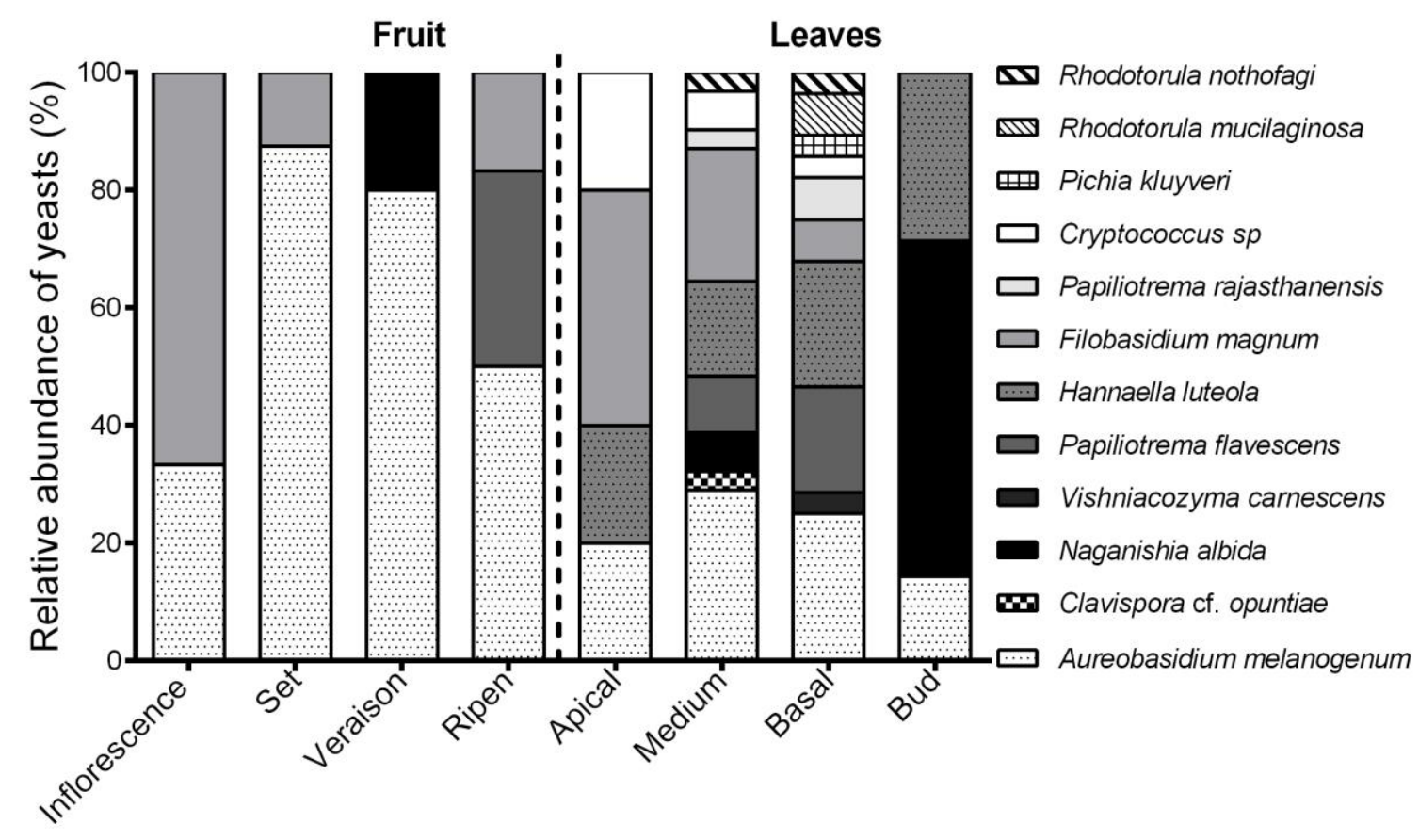

Figure 1. Relative abundance and distribution of the native yeast isolates found in the different grapevine organs

Abundância relativa e distribuição de isolados de leveduras nativas encontrados nos diferentes orgãos da videira.

Another species found was Pichia cf. kluyveri, whose use in winemaking has been previously reported by Ma et al. (2017), who evaluated the synthesis of volatile compounds during the co-inoculation of a $P$. cf. kluyveri with $S$. cerevisiae, obtaining an increased production of ethyl esters, fatty acids, among others. Concerning $R$. mucilaginosa, $\mathrm{Hu}$ et al. (2016) reported that this species possesses $\beta$-glucosidase activity that could promote the release of glycosylated terpens associated with floral aroma. On the other hand, regarding Clavispora genus, $C$. lusitaniae has been isolated from Mexican fermented beverages as 'mezcal' and 'sotol' (De La Garza-Toledo et al., 2008; Escalante-Minakata et al., 2008). In the present study, the identification of this isolate should be taken with caution, considering the low query coverage $(91 \%)$ and identity (96\%).

For the assays regarding winemaking potential, only those isolates belonging to such species previously reported to modify wine quality in mixed fermentation were included, namely $P$. cf. kluyveri, $C$. cf. opuntiae, $R$. mucilaginosa and $R$. nothofagi (Phaff et al., 1986; Wang et al. 2017; Wang et al. 2018b).

\section{In vitro selection tests}

\section{Killer activity and $\beta$-glucosidase activity}

Isolates $8 \mathrm{HM}, 4.7 \mathrm{HM}$ and $2 \mathrm{HE}$ belonging to Rhodotorula genus showed both killer activity and $\beta$ glucosidase activity (Table V), while $P$. cf. kluyveri 3.1HM showed killer activity, but not $\beta$-glucosidase activity. Finally, both $H$. uvarum controls (NB27 and NB108) showed $\beta$-glucosidase activity, but not killer activity, which coincides with previous studies (OrtizBarrera et al., 2015). The $\beta$-glucosidase activity could promote the release of glycolsylate terpenes associated with floral aroma, as $\mathrm{Hu}$ et al. (2016) found for other strains of $R$. mucilaginosa. Meanwhile Ma et al. (2017) obtained an increased production of ethyl esters, fatty acids, among others, while evaluating the synthesis of volatile compounds during the co-inoculation of a $P$. fermentans strain with $S$. cerevisiae. As mentioned in this and other previous studies, the evaluated features are strain dependent. 


\section{Sugar, total sulfur dioxide and ethanol tolerance}

The tolerance of isolates to limiting factors relevant for winemaking was, as expected, strain dependant (Figure 2). Yeasts belonging to Rhodotorula genus were the least tolerant to the three stress conditions tested. The inability of the Rhodotorula genus to tolerate stressful conditions is explained by the fact that must is composed by aerobic yeasts, which could be present and disappear in the first stages of fermentation due to the combined effect of $\mathrm{SO}_{2}$, low $\mathrm{pH}$, high ethanol and limited nitrogen concentrations (Jolly et al., 2014). Nevertheless, it is interesting to emphasize their practically null sugar tolerance, despite the fact that, according to these authors, it is a genus normally present in must. On the other hand, $C$. cf. opuntiae 5.7 HE and both H. uvarum controls (NB27 and NB108) outstood in sugar tolerance, which agrees with their previous characterization carried by Ortiz-Barrera et al. (2015). Moreover, Pichia cf. kluyveri 3.1HM was the most tolerant yeast to $30 \mathrm{mg} / \mathrm{L} \mathrm{SO}_{2}$. Several authors have observed that Pichia sp. possesses a wide range of $\mathrm{SO}_{2}$ tolerance (from $50 \mathrm{mg} / \mathrm{L}$ to $140 \mathrm{mg} / \mathrm{L}$ ) (Barata et al., 2008; Wang et al., 2018b). Finally, C. cf. opuntiae 5.7HE was the most tolerant to $5 \%$ ethanol, which is consistent with the fact that Clavispora genus has been found in two 'mezcal' distilleries (Kyrchmayr et al., 2017), and has been described as a vigorous fermenter (Phaff et al., 1986).

Table V

$\beta$-glucosidase activity and killer activity of different yeast isolates

Atividade $\beta$-glucosidase e atividade killer dos diferentes isolados de leveduras

\begin{tabular}{llcc}
\hline & & \multicolumn{2}{c}{ Activity } \\
\hline Species & Isolate & Killer & $\beta$-glucosidase \\
\hline Pichia cf. kluyveri & $3.1 \mathrm{HM}$ & + & - \\
Clavispora cf. opuntiae & $5.7 \mathrm{HE}$ & - & + \\
Rhodotorula mucilaginosa & $8 \mathrm{HM}$ & + & + \\
Rhodotorula mucilaginosa & $4.7 \mathrm{HM}$ & + & + \\
Rhodotorula nothofagi & $2 \mathrm{HE}$ & + & + \\
Hanseniaspora uvarum & Control NB108 & - & + \\
Hanseniaspora uvarum & Control NB27 & - & + \\
\hline
\end{tabular}

(+) presents the trait; (-) does not present the trait.

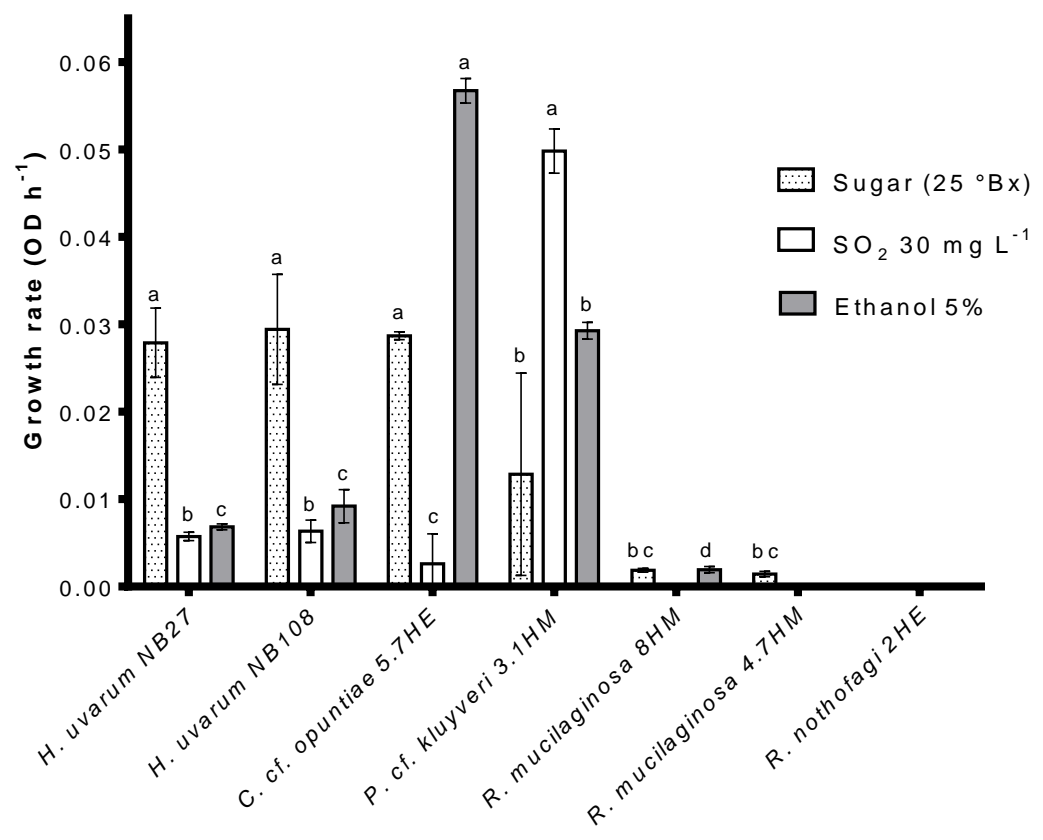

Figure 2. Growth rate under different stress conditions. Triplicate data are presented as mean \pm standard deviation. Bars (stress conditions) marked with the same letter are not significantly different (Tukey test, $\mathrm{p}>0.05$ ).

Taxa de crescimento em diferentes condições de stress. Dados em triplicado, apresentados como média \pm desvio padrão. Colunas (condições de stress) marcadas com a mesma letra não são significativamente diferentes (teste de Tukey, $p>0,05$ ). 


\section{Winemaking assays}

The isolate showing outstanding tolerance to limit factors, Pichia cf. kluyveri (3.1HM) and C. cf. opuntiae (5.7HE), were selected for the winemaking assays. In addition, the best $R$. mucilaginosa isolate (8HM) was considered, in the hypothesis that its killer and $\beta$-glucosidase activity might produce an important effect on wine. Finally, one $n-S$ yeast previously studied and reported (Ortiz-Barrera et al., 2015), namely $H$. uvarum NB108, was used as control.

For the differential quantification of Saccharomyces cerevisiae $\mathrm{N} 05$ and $\mathrm{n}-\mathrm{S}$ yeast during fermentations, lysine medium, selective for $\mathrm{n}$-S, was used.
Nevertheless, Saccharomyces was also able to grow due to their capacity to stock nitrogen in its vacuoles (Watson, 1976). Therefore, differential quantification of yeast in this medium was only possible for $R$. mucilaginosa (salmon color) and $P$. cf. kluyveri (rugged), both showing contrasting morphologies with S. cerevisiae.

Figure 3 shows the growth kinetics for $P$. cf. kluyveri $3.1 \mathrm{HM}$ and $S$. cerevisiae N05 (PS), and that for $R$. mucilaginosa 8HM and $S$. cerevisiae N05 (RS).The differences between the inoculum and viable counts of yeast in the inoculated must could be explained by the stress caused on microorganisms by the particularly complex environment, unusual for them.
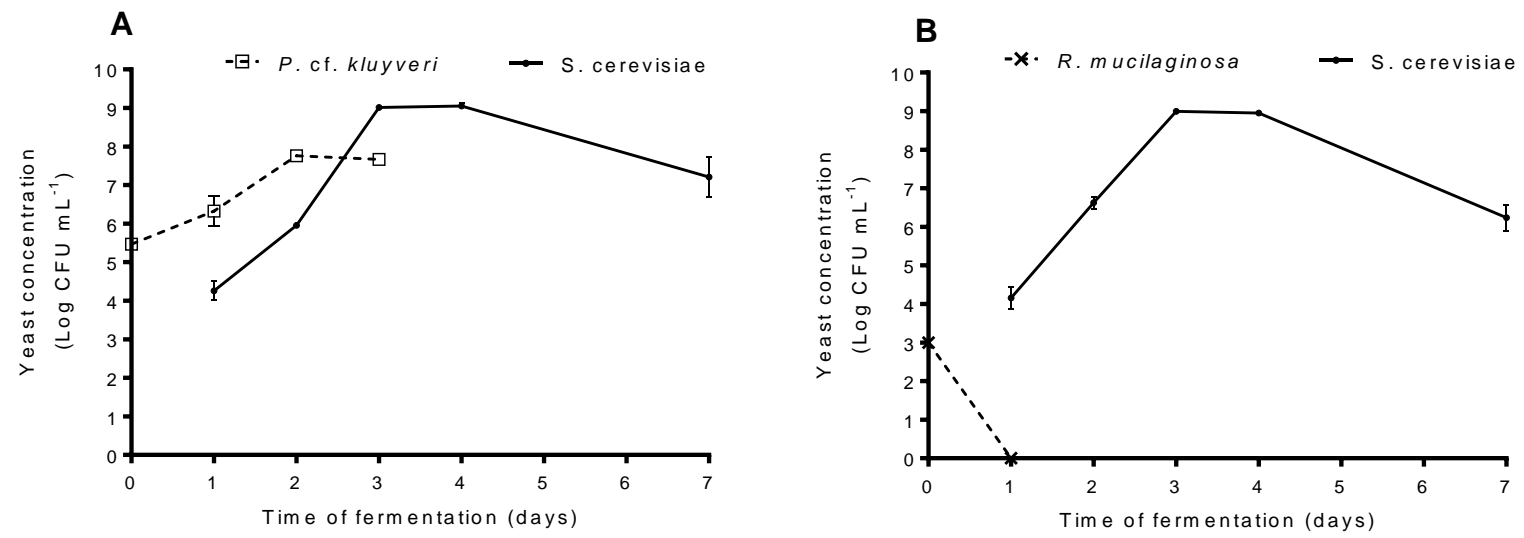

Figure 3. Growth kinetics, during fermentation, of S. cerevisiae N05 with P. cf. kluyveri 3.1HM (A), and with R. mucilaginosa 8HM (B).

Cinética de crescimento, durante a fermentação, de S. cerevisiae N05 com P.cf. kluyveri 3.1HM (A), e com R. mucilaginosa 8HM (B).

$P$. cf. kluyveri 3.1HM population increased to a final count of approximately $8 \mathrm{Log} \mathrm{CFU} / \mathrm{mL}$ two days after its inoculation. At the same time (24 hours after its inoculation) S.cerevisae N05 population arrived to 5 Log CFU/mL. Afterwards, S. cerevisiae adapted and actively multiplied, increasing $4 \mathrm{Log} \mathrm{CFU} / \mathrm{mL}$ in 24 $\mathrm{h}$, and reaching a population close to $9 \mathrm{Log} \mathrm{CFU} / \mathrm{mL}$, while $P$. cf. kluyveri $3.1 \mathrm{HM}$ reached the stationary phase (Figure 3A). On the other treatment, $R$. mucilaginosa $8 \mathrm{HM}$ was not detected after $24 \mathrm{~h}$ from its inoculation and $\mathrm{S}$. cerevisiae N05 arrived to more than $6 \mathrm{Log} \mathrm{CFU} / \mathrm{mL} 24 \mathrm{~h}$ after its inoculation (Figure 3B). On mixed fermentations, $P$. cf. kluyveri $3.1 \mathrm{HM}$ rapidly adapted to the medium which coincides with its relative tolerance to $\mathrm{SO}_{2}$, ethanol and sugar (Figure 2). Meanwhile, $R$. mucilaginosa 8HM evidenced its incapacity to adapt under must conditions (sugar,
$\mathrm{SO}_{2}, \mathrm{pH}$ and nitrogen deficiency), previously observed in the tolerance assays (Figure 2).

Finally, the behavior of $S$. cerevisiae N05 was similar in both mixed fermentations, with a slightly lower viability 24 hours after having been inoculated in presence of $P$. cf. kluyveri 3.1HM, in relation to that obtained at the same time in presence of $R$. mucilaginosa $8 \mathrm{HM}$, probably due to some competition offered by this $\mathrm{n}-\mathrm{S}$ isolate in the first case, associated to the higher concentration of $P$. cf. kluyveri ( 2 Log CFU/mL) than that of $S$. cerevisiae at this time. As any other organism, yeast competes for space and resources in a shared environment with other yeasts, which is observed in the mixed fermentation with $R$. mucilaginosa $8 \mathrm{HM}$, where only $S$. cerevisiae prevailed, taking advantage of space and/or nutrients available, which contrast with its behavior in the presence $P$. cf. kluyveri 3.1HM. 


\section{Physical and chemical analyses of wines}

Differences among treatments were only found for $\mathrm{pH}$ and volatile acidity, being the control $S$. cerevisiae N05 with $H$. uvarum NB108 (HS) the highest in both (3.75 and $0.45 \mathrm{~g} / \mathrm{L}$ acetic acid, respectively) (Table VI). Differences in $\mathrm{pH}$ could be explained by the different concentrations of succinic, lactic, piruvic and malic acids and other acids produced by the distinct $\mathrm{n}-\mathrm{S}$ yeasts during fermentation (Whiting, 1976; Chidi et al., 2018). Nevertheless, no differences between treatments in TTA were apparent. The higher volatile acidity obtained in the co-inoculation of Hanseniaspora uvarum NB108 agrees with Jolly et al. (2014) who reported that Hanseniaspora species produce high quantities of acetic acid and ethyl acetate, which make them less attractive for winemaking. Ortiz-Barrera et al. (2015) performed mix fermentations with $S$. cerevisiae and different Hanseniaspora strains, finding values of volatile acidity lower than $0.2 \mathrm{~g} / \mathrm{L}$ acetic acid, which differ from our results, probably due to differences in winemaking conditions.

Concerning the other analyzed variables, residual sugars, less than $2 \mathrm{~g} / \mathrm{L}$, and alcohol strength, higher than $13 \%$, correspond to dry wines and confirm complete fermentations. Moreover, total $\mathrm{SO}_{2}$ values are under the limits accepted for quality wines (OIV, 2019a). These results show that $n-S$ yeast evaluated in this study do not have any negative impact in the chemical characteristics of wines and could be used in commercial mix fermentations. Nevertheless, the most recognized contribution of $\mathrm{n}-\mathrm{S}$ lays down on subtle sensory attributes, which seem to provide complexity and tipicity to wine (Jolly et al., 2014).

\section{Table VI}

$\mathrm{pH}$, total titritable acidity (TTA), volatile acidity (VA), alcohol strength, residual sugars and total sulfur dioxide of 'Tempranillo' wines elaborated with different mixed fermentations

pH, acidez total (TTA), acidez volátil (VA), título alcoométrico, açúcares residuais e dióxido de enxofre total de vinhos da casta 'Tempranillo' elaborados com base em diferentes fermentações mistas

\begin{tabular}{|c|c|c|c|c|c|c|}
\hline Treatment & $\mathrm{pH}$ & $\begin{array}{c}\text { TTA } \\
\text { (g tartaric acid/L) }\end{array}$ & $\begin{array}{c}\text { VA } \\
(\mathrm{g} \text { acetic acid/L) }\end{array}$ & $\begin{array}{l}\text { Alcohol } \\
\text { strength } \\
(\% \mathrm{v} / \mathrm{v})\end{array}$ & $\begin{array}{c}\text { Residual } \\
\text { sugars } \\
\text { (g/L) }\end{array}$ & $\begin{array}{c}\text { Total } \mathrm{SO}_{2} \\
(\mathrm{mg} / \mathrm{L})\end{array}$ \\
\hline RS & $3.67 \pm 0.02^{\mathrm{bc}}$ & $7.39 \pm 0.11^{\mathrm{a}}$ & $0.22 \pm 0.03^{\mathrm{b}}$ & $12.97 \pm 1.6^{\mathrm{a}}$ & $1.85 \pm 0.02^{\mathrm{a}}$ & $117.33 \pm 15.79^{a}$ \\
\hline PS & $3.66 \pm 0.01^{\mathrm{c}}$ & $7.59 \pm 0.11^{\mathrm{a}}$ & $0.27 \pm 0.02^{\mathrm{b}}$ & $13.63 \pm 0.47^{\mathrm{a}}$ & $1.69 \pm 0.17^{\mathrm{a}}$ & $124.80 \pm 6.40^{\mathrm{a}}$ \\
\hline CS & $3.65 \pm 0.04^{\mathrm{c}}$ & $7.62 \pm 0.15^{\mathrm{a}}$ & $0.25 \pm 0.02^{\mathrm{b}}$ & $13.75 \pm 0.62^{\mathrm{a}}$ & $1.66 \pm 0.13^{\mathrm{a}}$ & $117.33 \pm 7.39^{\mathrm{a}}$ \\
\hline HS & $3.75 \pm 0.01^{\mathrm{a}}$ & $7.59 \pm 0.07^{\mathrm{a}}$ & $0.45 \pm 0.03^{\mathrm{a}}$ & $13.98 \pm 0.81^{\mathrm{a}}$ & $1.71 \pm 0.10^{\mathrm{a}}$ & $118.40 \pm 6.40^{\mathrm{a}}$ \\
\hline N05 & $3.72 \pm 0.02^{\mathrm{ab}}$ & $7.44 \pm 0.20^{\mathrm{a}}$ & $0.19 \pm 0.05^{\mathrm{b}}$ & $13.16 \pm 0.18^{\mathrm{a}}$ & $1.64 \pm 0.11^{\mathrm{a}}$ & $130.13 \pm 3.70^{\mathrm{a}}$ \\
\hline
\end{tabular}

Mean and standard deviation from three replicates are shown. Means followed by the same letter in a column are not significantly different (Tukey test, $\mathrm{p}>0.05$ ). Mix fermentation treatments of $S$. cerevisiae N05 with: R. mucilaginosa $8 \mathrm{HM}$ (RS), P. cf. kluyveri $3.1 \mathrm{HM}$ (PS), C. cf. opuntiae 5.7 HM (CS); as mix control with H. uvarum NB108 (HS) and general control: S. cerevisiae alone (N05).

\section{CONCLUSIONS}

Yeast populations in grapevines vary highly depending of the organ and the sampling season, and all the isolates correspond to non-Saccharomyces yeasts. The prevalent genera in the vineyard are the highly oxidative genus Aureobasidium and basidiomycota yeasts.

Pichia cf. kluyveri 3.1HM showed killer activity, was the most tolerant to sulfite and survives along the exponential phase of $S$. cerevisie. Clavispora cf. opuntiae 5.7HM showed the highest tolerance to ethanol and sugar, as well as $\beta$-glucosidase activity.
Both strains should be further studied in mixed fermentations for the production of regional wines. On the other hand, the different Rhodotorula spp.isolates evaluated lacked tolerance to the stress conditions evaluated and R. mucilaginosa 8HM was not able to grow in the must environment.

This study provided insights on the diversity of yeast present in distinct parts of grapevines established in Queretaro, Mexico, and revealed the oenological potential of Pichia cf. kluyveri 3.1HM. 


\section{REFERENCES}

Barata A., Malfeito-Ferrera M., Loureiro V., 2012. The microbial ecology of wine grape berries. Int. J. Food Microbiol., 153, 243259.

Barata A., Seborro F., Belloch C., Malfeito-Ferrera M., Loureiro V., 2008. Ascomycetous yeast species recovered from grape damaged by honeydew and sour rot. J. Appl. Microbiol., 104, 11821191.

Belda I., Conchillo L.B., Ruiz J., Navascués E., Marquina D., Santos A., 2016.Selection and use of pectinolytic yeasts for improving clarification and phenolic extraction in winemaking. Int. J. Food Microbiol., 223, 1-8

Bernardi A.M., 2013. Selección de levaduras vínicas provenientes de la provincia de Mendoza. 54 p. PhD Thesis, Facultad de Ciencias Agrarias, Universidad Nacional de Cuyo.

Bokulich N.A., Thorngate J.H., Richardson P.M., Mills D.A., 2013. Microbial biogeography of wine grapes is conditioned by cultivar, vintage, and climate. Proc. Natl. Acad. Sci. U.S.A., 111, 139-148.

Callejón R.M., Clavijo A., Ortigueira P., Troncoso A.M., Paneque P., Morales M.L., 2010. Volatile and sensory profile of organic red wines produced by different selected autocthonus and commercial Saccharomyces cerevisiae strains. Anal. Chim. Acta., 660, 68-75.

Capozzi V., Garofalo C., Chiriatti M.A., Grieco F., Spano G., 2015. Microbial terroir and food innovation: the case of yeast biodiversity in wine. Microbiol. Res., 181, 75-83.

Chidi B.S., Bauer F.F., Rossouw D. 2018. Organic acid metabolism and the impact of fermentation practices on wine acidity: A review. S. Afr. J. Enol. Vitic., 39, 1-15.

Crespo-Sampere A., Estiarte N., Marín S., Sanchis V., Ramos A.J., 2013. Propidium monoazid combined with real-time quantitative PCR to quantify viable Alternaria spp. contamination in tomato products. Int. J. Food Mucrobiol., 165, 214-220.

Cordero-Bueso G., Arroyo T., Serrano A., Tello J., Aporta I., Vélez M.D., Valero E., 2011. Influence of the farming system and vine variety on yeasts communities associated with grape berries. Int. J. Food Microbiol., 145, 132-139.

De La Garza-Toledo H., Martínez M., Lara L., Rodríguez-Herrera R., Rodríguez-Martínez J., Aguilar C. N., 2008. Production of a Mexican alcoholic beverage: Sotol. Res. J. Biol. Sci., 3, 566-571.

Escalante-Minakata P., Blaschek H.P., Barba de la Rosa A.P., Santos L., De León-Rodríguez A., 2008. Identification of yeast and bacteria involved in the mezcal fermentation of Agave salmiana. Lett. Appl. Microbiol., 46, 626-630.

Esteve-Zarzoso B., Belloch C., Uruburu F., Querol A., 1999. Idenfication of yeasts by RFLP analysis of the 5.8S rRNA gene and the two ribosomal internal transcribed spacers. Int. J. Syst. Bacteriol., 49, 329-337.

Fleet G H.. 2003. Yeast interactions and wine flavour. Int. J. Food Microbiol., 86, 11-22.

Garijo P., López R., Santamaría P., Ocón E., Olarte C., Sanz S., Gutiérrez A., 2011. Presence of enological microorganisms in the grapes and the air of a vineyard during the ripening period. Eur. Food Res. Technol., 233, 359-365.

Grube M., Schimd F., Berg G., 2011. Black fungi and associates bacterial communities in the phyllospehere of grapevine. Bull. $\mathrm{Br}$. Mycol. Soc., 115, 978-986.

Hu K., Zhu X.L., Mu H., Ma Y., Ullah N., Tao, Y.S., 2016. A novel extracellular glycosidase activity from Rhodotorula mucilaginosa: its application potential in wine aroma enhancement. Let. Appl. Microbiol., 62, 169-176.

Jolly N. P, Varela C., Pretorius I.S., 2014. Not your ordinary yeast: non-Saccharomyces yeasts in wine production uncovered. FEMS Yeast Res., 14, 215-237.

Kyrchmayr M., Segura-García L.E., Lappe-Oliveras P., MorenoTerrazas R., De la Rosa M., Mathis A.G., 2017. Impact of environmental conditions and process modifications on microbial diversity, fermentation efficiency and chemical profile during the fermentation of mescal in Oaxaca. Food Sci. Technol., 79, 160-169.

Li S., Cheng C., Li Z., Chen J., Yan B., Han B., Reeves M., 2010. Yeasts species associated with wine grapes in China. Int. J. Food Microbiol., 138, 85-90.

Liu P-T, Lu L., Duan C-Q, Yan G.-L., 2016. The contribution of indigenous non-Saccharomyces wine yeast to improved aromatic quality of Cabernet Sauvignon wines by spontaneous fermentation. LWT - Food Sci. Technol., 71, 356-363.

Lopes C.A., Sangorrin, M.P., 2010. Optimization of killer assays for yeast selection protocols. Rev. Argent. Microbiol., 42, 298-306.

Ma D., Yan X., Wang Q., Zhang, Y., Tao Y., 2017. Performance of selected $P$. fermentans and its excellular enzyme in co-inoculation with $S$. cerevisiae for wine aroma enhancement. Food Sci. Technol., 86, 361-370.

Mendes S.D.C., Ramírez-Castrillón M., Feldberg N.P., Bertoldi F.C., Valente P., 2017. Environmetal yeasts communities in vineyards in the mountains of Santa Catarina State, Brazil. World J. Microbiol. Biotechnol., 33, 128.

Miranda-Castilleja D.E., Aldrete-Tapia J.A., Arvizu-Medrano S.M., Hernández-Iturriaga M., Soto-Muñoz L., Martínez-Peniche R.Á., 2017. Growth kinetics for the selection of yeast strains for fermented beverages. In: Yeast-Industrial application I. 87-67. Morata A., Loira I.(eds.), Intech, Rijeka.

Miranda-Castilleja D.E., Ortiz-Barrera E., Arvizu-Medrano S.M., Ramiro-Pacheco J., Aldrete-Tapia J.A., Martínez-Peniche, R.Á., 2015. Isolation, selection and identification of native Saccharomyces spp.yeasts form vineyards in Querétaro, México. Agrociencia, 49, 759-773.

OIV, 2019a. International code of oenological practices. 431 p. International Organisation of Vine and Wine, Paris

OIV, 2019b. Compendium of international methods of wine and must analysis. Vol 1.593 p. International Organisation of Vine and Wine, Paris.

Ortiz-Barrera E., Miranda-Castilleja D.E., Arvizu-Medrano S.M., Pacheco-Aguilar J.R., Aldrete-Tapia J.A., Hernández-Iturriaga M., Martínez-Peniche R.A. 2015. Enological potential of native nonSaccharomyces yeasts from vineyards established in Querétaro, México. RCHSH, 21, 169-183.

Padilla B., García-Fernández, D., González B., Izidoro I., EsteveZarzoso B., Beltran G., Mas A., 2016b. Yeast biodiversity from DOQ Priorat uninoculated fermentations. Front. Microbiol., 7, 930.

Padilla B., Gil J.V., Manzanares P., 2016a. Past and future of nonSaccharomyces yeasts: from spoilage microorganisms to biotechnological tools for improving wine aroma complexity. Front. Microbiol., 7, 411.

Pérez G., Fariña L., Barquet M., Boido E., Gaggero C., Dellacassa E., Carrau F., 2011. A quick screening method to identify $\beta$ glucosidase activity in native wine yeast strains: Application of Esculin Glycerol Agar (EGA) medium. World J. Microbiol. Biotechnol., 27, 47-55. 
Pérez-Martín F., Seseña S., Fernández-González M., Arévalo M., Llanos M., 2014. Microbial communities in air and wine of a winery in two consecutive vintage. Int. J. Food Microbiol., 190, 144-153.

Phaff H.J., Miranda M., Starmer W.T., Tredick J., Barker J.S.F., 1986. Clavispora opuntiae, a new heterothallic yeast occurring in necrotic tissue of Opuntia species. Int. J. Syst. Bacteriol., 36, 372379.

Pinto C., Pinho D., Sousa S., Pinheiro M., Egas C., Gomes A., 2014. Unravelling the diversity of grapevine microbiome. PLOS ONE, 9, e85622.

Ribéreau-Gayon P., Glories Y., Maujean A., Dubourdieu D., 2006. Handbook of Enology: The microbiology of wine and vinifications. 497 p. University of Bordeaux II, Bordeaux.

Varela C., 2016. The impact of non-Saccharomyces yeasts in the production of alcoholic beverages. App. Microbiol. Biotechnol., 100, 9861-9874.

Varela C., Borneman A.R., 2016. Yeasts found in vineyards and wineries. Yeast, 34, 111-128.

Wang X.C., Li A.H., Dizy M., Ullah N., Sun W.X, Tao Y.S., 2017. Evaluation of aroma enhancement for "Ecolly" dry white wines by mixed inoculation of selected Rhodotorula mucilaginosa and Saccharomyces cerevisiae. Food Chem., 228, 550-559.

Wang Y., Li Y., Xu W., Zheng X., Zhang, X., Abdelhai M., Zhao L., Li, H., Diao J., Zhang H., 2018a. Exploring the effect of $\beta$ glucan on the biocontrol activity of Cryptococcus podzolicus against postharvest decay of apples and the possible mechanisms involved. BioControl, 121, 14-22.

Wang Y., Zhao Y.C., Fan L.L., Xia X.D., Li Y.H., Zhou J.Z., 2018b. Identification and characterization of Pichia membranifaciens Hmp-1 isolated from spoilage blackberry wine. $J$. Integr. Agric., 17, 2126-2136.

Watson T.G., 1976. Amino-acid pool composition of Saccharomyces cerevisiae as a function of growth rate and aminoacid nitrogen source. Microbiol., 96, 263-268.

Whiting G.C., 1976. Organic acid metabolism of yeast during fermentation of acloholic beverages - A Review. J. Inst. Brew., 82, 84-92

Zanol G.C., Baleiras-Couto M.M., Duarte F.L., 2010. Restriction profiles of 26s rDNA as a molecular approach for wine yeasts identificacion. Ciência Tec Vitiv., 17, 75-85. 